\title{
Comparison of five conventional methods and capnography in the detection of tube placement in endotracheal intubation
}

\author{
Endotrakeal entübasyonda tüp yerleşiminin tespitinde beş konvansiyonel yöntem ve \\ kapnografinin karşılaştırılması
}

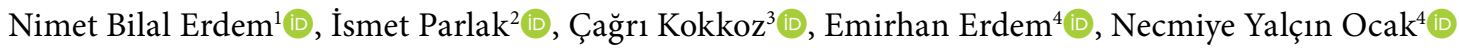 \\ ${ }^{1}$ Department of Emergency Medicine, İzmir Katip Çelebi Atatürk Training and Research Hospital, İzmir, Turkey \\ ${ }^{2}$ Department of Emergency Medicine, İzmir Bozyaka Training and Research Hospital, İzmir, Turkey \\ ${ }^{3}$ Department of Emergency Medicine, Çiğli Regional Education Hospital, İzmir, Turkey \\ ${ }^{4}$ Department of Emergency Medicine, İzmir Tepecik Training and Research Hospital, İzmir, Turkey
}

\section{ABSTRACT}

Objectives: The aim of this study was to compare the sensitivity and specificity of the conventional methods with the gold standard method, capnography for detection of endotracheal tube (ETT) intubation, and the reliability of these conventional methods when the capnometer device is unavailable.

Patients and methods: In this prospective cross-sectional study, patients were chosen according to inclusion criteria. The tube's passing through the vocal cords, blurring of ETT, hearing bilateral and equal sounds on lung auscultation, not hearing sounds on stomach auscultation, and observing chest expansion were the conventional methods used for confirmation of the ETT position.

Results: A total of 84 patients who met inclusion criteria were included in the study. Outcomes of 96 intubations were evaluated. For confirmation of ETT position, sensitivity of the tube's passing through the vocal cords was $93 \%$, specificity was $100 \%$, positive predictive value (PPV) was $100 \%$, and negative predictive value (NPV) was $67 \%$. Sensitivity of lung auscultation was $100 \%$, specificity was $83 \%$, PPV was $98 \%$, and NPV was $100 \%$. Sensitivity of stomach auscultation was $90 \%$, specificity was $100 \%$, PPV was $100 \%$, and NPV was $45 \%$. When lung and stomach auscultation were evaluated together, sensitivity, specificity, PPV, and NPV were $100 \%$.

Conclusion: We believe that the tube's passing through the vocal cords, hearing bilateral and equal sounds on lung auscultation, and hearing no sounds on stomach auscultation could be used for confirming ETT position in the absence of capnography however the combined use of these methods is more reliable and effective.

Keywords: Capnography; confirmation; intubation.

\section{$\ddot{O Z z}$}

Amaç: Bu çalışmanın amacı, endotrakeal tüp (ETT) entübasyonunu saptamak için konvansiyonel yöntemlerin duyarlılık ve özgüllüğünü ve altın standart yöntem, kapnografi ve kapnografi cihazı bulunmadığında bu geleneksel yöntemlerin güvenilirliğini karşılaştırmaktır.

Hastalar ve yöntemler: Bu prospektif kesitsel çalışmada, hastalar dahil etme kriterlerine göre seçildi. Tüpün ses tellerinden geçmesi, ETT'nin bulanıklaşması, akciğerde oskültasyonda iki taraflı ve eşit seslerin duyulması, mide oskültasyonunda işitme seslerinin duyulmaması ve göğüs genişlemesinin gözlemlenmesi ETT pozisyonunun doğrulanması için kullanıldı.

Bulgular: Dahil etme kriterlerini karşılayan toplam 84 hasta çalışmaya dahil edildi. Toplam 96 entübasyonun sonuçları değerlendirildi. Endotrakeal tüp pozisyonunun doğrulanması için, tüpün vokal kordlardan geçme duyarlılı̆̆ \%93, özgüllük \%100, pozitif kestirim değeri (PPV) \%100 ve negatif kestirim değeri (NPV) \%67 idi. Akciğer oskültasyonunun duyarlıı̆ı \%100, özgüllük \%83, PPV \%98 ve NPV \%100 idi. Mide oskültasyonunun duyarlılı̆̆ \%90, özgüllük \%100, PPV \%100 ve NPV \%45 idi. Akciğer ve mide oskültasyonu birlikte değerlendirildiğinde duyarlılık, özgüllük, PPV ve NPV \%100 olarak bulundu. Sonuç: Tüpün vokal kordlardan geçmesi, iki taraflı ve eşit seslerin akciğer oskültasyonunda duyulması ve mide oskültasyonunda sesler duyulmaması, entübasyon uygulandığında kapnografinin yokluğunda ETT'nin doğrulanması için kullanılabileceğini düşünüyoruz ancak bu yöntemlerin kombine olarak kullanıldığında daha güvenilir ve etkilidir.

Anahtar sözcükler: Kapnografi; doğrulama; entübasyon.

Received: September 16, 2018 Accepted: October 12, 2018

Correspondence: Çağrı Kokkoz. Çiğli Bölge Eğitim Hastanesi, Acil Tıp Kliniği, 35620 Çiğli, İzmir, Turkey. Tel: +90536 - 9795590 e-mail: cagrikokkoz@gmail.com 
Although various methods are available for confirming endotracheal tube (ETT) position in intubation, all have some degree of limitation. Therefore combination of more than one method is used in clinical practice. The methods used for this purpose include observing the tube's passing through vocal cords, blurring of ETT, lung and stomach auscultation, observing chest expansion, oxygen saturation monitoring, chest $\mathrm{X}$-ray, and end-tidal carbon dioxide $\left(\mathrm{ETCO}_{2}\right)$ measurement. ${ }^{[1]}$ While $\mathrm{ETCO}_{2}$ measurement is recommended for confirming the ETT position by the Cardiac Advanced Life Support-Surgical (CALS-S) guideline 2000 by American Heart Association (AHA, the CALS-S 2010 guideline recommends capnography as the gold standard method. ${ }^{[2,3]}$ However it has some limitations such as false negativity and false positivity and is not commonly used in emergency departments (ED) due to the absence of an $\mathrm{ETCO}_{2}$ measurement device or technical defects. ${ }^{[4]}$

The American College of Emergency Physicians (ACEP) reported in 2001 that $\mathrm{ETCO}_{2}$ measurement is the most accurate and easiest applied method for confirmation of endotracheal intubation in patients who have adequate tissue perfusion. ${ }^{[5]}$

In case of esophageal intubation, although the smallest amount of $\mathrm{CO}_{2}$ in the stomach is perceived by the device, $\mathrm{ETCO}_{2}$ value becomes zero after breathing. Therefore $\mathrm{ETCO}_{2}$ measurement is recommended after six breaths. ${ }^{[6]}$ Esophageal intubation should be suspected if $\mathrm{ETCO}_{2}$ value is near zero in a patient without ventilation or perfusion disorder.

In this study, we aimed to compare the sensitivity and specificity of the conventional methods and capnography for detection of the location of endotracheal tube (ETT) following intubation, and to evaluate the reliability of these conventional methods when capnography is unavailable.

\section{PATIENTS AND METHODS}

\section{Study setting and population}

Our study was a single centered prospective cross-sectional study and was conducted at the Emergency Medicine Clinic of İzmir Bozyaka Research and Training Hospital between April 14,
2017 and July 15, 2017. Local ethics committee approval was obtained prior to the study.

Patients who underwent endotracheal intubation in ED, who were over 18 years of age, and whose vital signs were obtained on admission were included in the study. Exclusion criteria included trauma, pneumothorax, chest deformity, neck malignity or deformation, being under 18 years of age, and prior cardiopulmonary arrest before arriving at the hospital. A total of 96 patients underwent endo-tracheal intubation during the study period. Of these 96 patients, 10 patients with multi-trauma, one patient under 18 years of age, and one patient with a known pneumothorax were excluded from the study. The remaining 84 patients ( 42 male, 42 female; mean age $71.7 \pm 15$ years) who met inclusion criteria were included in the study.

Demographic data, blood pressure, heart rate, respiration rate, fever, oxygen saturation, cause of admission to ED, comorbid conditions, cause of intubation, and diagnoses of the patients who were intubated under elective conditions were recorded in a data collection form.

Intubations were applied by a physician who had at least one year of emergency medicine education and at least one advanced airway management experience. Macintosh blade laryngoscope was used for intubation. The cuff of the ETT was inflated with $10 \mathrm{cc}$ air using a $10 \mathrm{cc}$ syringe before intubation. A guide-wire was placed into the intubation tubes. Mouth side was fixed at $23 \mathrm{~cm}$ for males and $21 \mathrm{~cm}$ for females. $\mathrm{Ambu}^{\circledR}$ brand of adult type 1.5 lt volume of balloon mask was used for aeration.

Five conventional methods were specified for confirmation of the location of endotracheal intubation: the ETT's passing through the vocal cords, blurring of ETT, hearing bilateral and equal sounds on lung auscultation, hearing no sounds on stomach auscultation, and chest expansion. Lung auscultation was performed from the third intercostal space. Chest expansion was evaluated according to bilateral chest wall movements. The researcher/s was/were blinded to $\mathrm{ETCO}_{2}$ values during assessment of conventional methods. The methods were verified using EMMA $^{\circledR}$ brand of mainstream capnography at the end of the assessment. Approximately 500-600 cc of air was administered with the balloon mask after 
intubation and measurement of $\mathrm{ETCO}_{2}>5 \mathrm{mmHg}$ together with a typical wave form at the end of six ventilations were accepted as trachea intubation. Trachea intubation was considered unsuccessful if $\mathrm{ETCO}_{2} \leq 5 \mathrm{mmHg}$.

\section{Statistical analysis}

IBM SPSS version 21.0 (IBM Corp., Armonk, NY, USA) statistical package program was used for statistical analysis. Positivity of passing through vocal cords, positivity of blurred tube, positivity of lung sounds, negativity of stomach sounds, positivity of chest expansion; lung sounds + stomach sounds, passing from vocal cords + lung sounds + stomach sounds variables were compared with $\mathrm{ETCO}_{2}$ positivity and sensitivity, specificity, positive predictive value (PPV), negative predictive value (NPV), and confidence intervals of these values were determined.

\section{RESULTS}

A total of 18 patients (21.4\%) who developed arrest during their follow-up at ED were applied urgent endotracheal intubation. Indications of endotracheal intubation were hypoxia in 20 patients (23.8\%), low Glasgow Coma Scale score $(<8)$ in 22 patients $(26.1 \%)$, preservation of airway safety in 18 patients (221.4\%), and hypercarbia in six patients (7.1\%).

While endotracheal intubation was achieved in the first attempt in 73 out of 84 patients (86.9\%), it was achieved in the second attempt in 11 patients $(13.09 \%)$ and in the third attempt in one patient (1.19\%).

For confirmation of the ETT position; sensitivity of passing through the vocal cords was 93\% (confidence interval [CI] 87\%-98\%), specificity was $100 \%$ (CI: 100\%-100\%), PPV was $100 \%$ (CI: $100 \%-100 \%)$, and NPV was $67 \%$ (CI: $45 \%-88 \%)$. For blurring of ETT; sensitivity was $96 \%$ (CI: 92\%-100\%), specificity was 50\% (CI: 22\%-78\%), PPV was 93\% (CI: 88\%-98\%), and NPV was 67\% (CI: 36\%-97\%). For evaluation with lung auscultation; sensitivity was 100\% (CI: 100\%$100 \%$ ), specificity was $83 \%$ (CI: 62\%-100\%), PPV was 98\% (CI: 94\%-100\%), and NPV was 100\% (CI: 100\%-100\%). For evaluation with stomach auscultation; sensitivity was 90\% (CI: 84\%-97\%), specificity was 100\% (CI: 100\%-100\%), PPV was 100\% (CI: 100\%-100\%), and NPV was 45\% (CI: 23\%-67\%). For evaluation with chest expansion, sensitivity was 87\% (CI: 80\%-94\%), specificity was 75\% (CI: 51\%-100\%), PPV was 96\% (CI: 92\%-100\%), and NPV was 45\% (CI: 23\%-67\%).

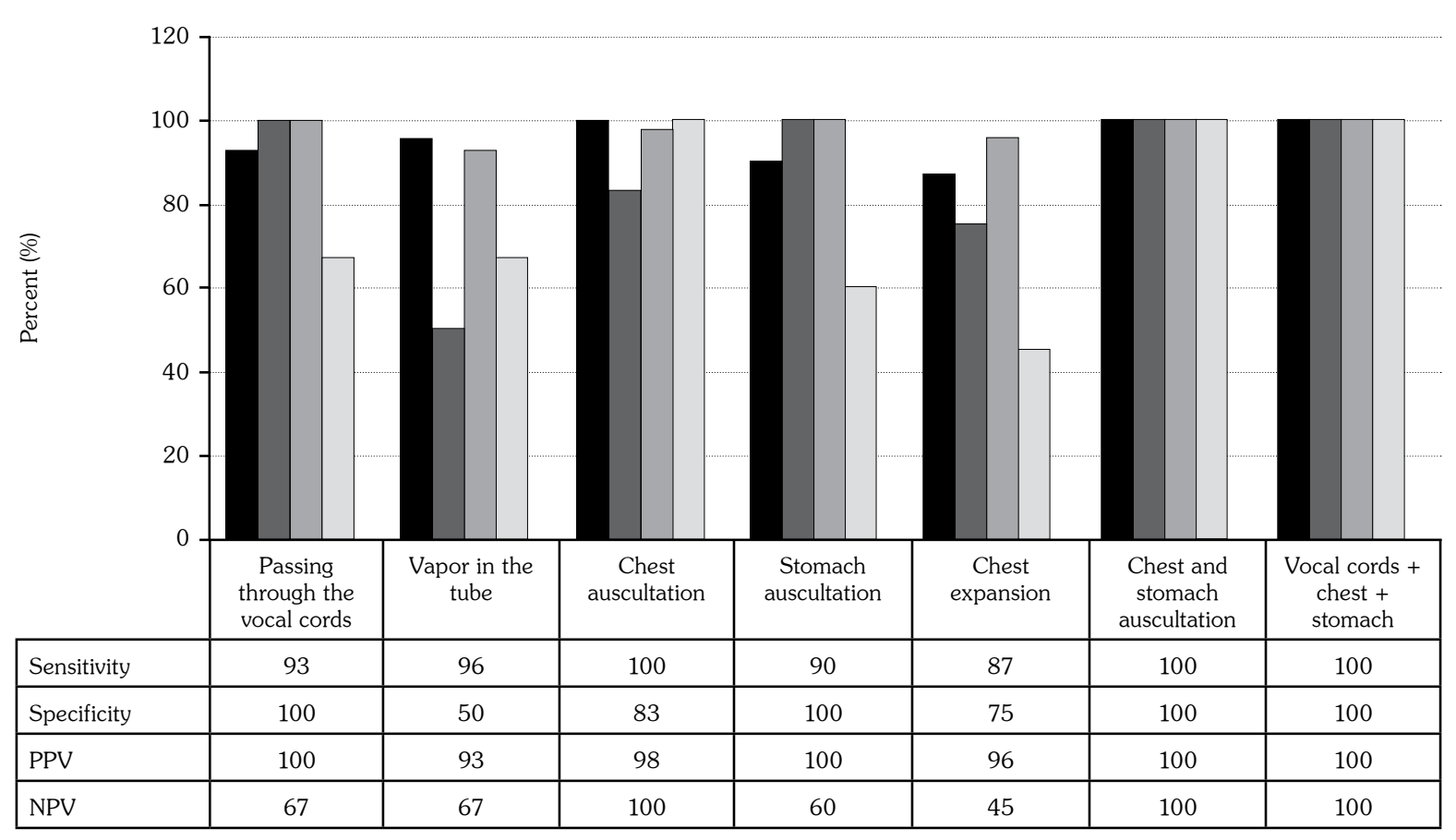

Figure 1. Comparison of the conventional methods for confirmation of the location of endotracheal tube. PPV: Positive predictive value; NPV: Negative predictive value. 
When lung and stomach auscultation was evaluated together, sensitivity, specificity, PPV, and NPV were found as $100 \%$. When passing through vocal cords, lung auscultation, and stomach auscultation were evaluated together, sensitivity, specificity, PPV, and NPV were found as 100\%. Figure 1.

\section{DISCUSSION}

End-tidal carbon dioxide measurement system, which first came into use in the 1970s, has been used routinely in emergency departments and operating rooms for approximately 25 years. The 2010 AHA Advanced Cardiovascular Life Support (ACLS) recommends $\mathrm{ETCO}_{2}$ measurement as the most reliable method for confirming the position of the ETT. However it is unavailable in many countries and many emergency medicine departments and not commonly used when available. ${ }^{[4]}$ In this case, conventional methods became dominant. Therefore we believe that confirmation of the ETT position by using one or more of the conventional methods is significant.

Despite the large number of studies investigating the significance of $\mathrm{ETCO}_{2}$ measurement, studies that investigate $\mathrm{ETCO}_{2}$ measurement using the conventional methods are limited. Very few studies have investigated the reliability of the conventional methods in the last 20 years.

Although observing of the ETT passing through the vocal cords has been used as a conventional method for confirming ETT position, few studies have investigated the reliability of this method. Since only author opinions are available, no comparisons could be made. In our study, sensitivity of this method was found as 93\% and specificity as 100\%; the method was found to have high diagnostic value for confirming the ETT position.

We could not find another study to compare to our study. However we found publications which evaluated one or more of these methods. Although $\mathrm{ETCO}_{2}$ is accepted as the gold standard today, it was not considered the gold standard when those publications were being conducted. Therefore we made comparisons with appropriate studies which included one or more of the conventional methods.
The conventional methods, lung auscultation, stomach auscultation, chest expansion and blurring of the tube, were evaluated in a study by Andersen and Hald ${ }^{[7]}$ which included 40 patients who were planned to undergo gynecologic laparotomy. The study was conducted by 12 anesthetists and 10 anesthesia nurses as a blinded randomized study. Forty patients underwent both trachea and esophagus intubation, and head and neck regions of the patients were closed with an opaque cover. Researchers tried to estimate whether the patient was applied esophagus or trachea intubation by performing lung auscultation from both axillae, stomach auscultation, chest expansion, and evaluating blurred tube. All patients were evaluated twice so as to evaluate both esophagus and trachea intubation findings. Esophageal detector device was used for confirming the ETT position. The authors detected both esophagus and trachea intubation correctly with bilateral axillae and stomach auscultation. Although lung auscultation from bilateral axillae yielded 100\% correct results for trachea intubation, it yielded $15 \%$ false negative results for assessment of esophagus intubation and rate of correct detection was $85 \%$. While blurring of ETT is seen in $100 \%$ of trachea intubations, it yielded false positive results in $85 \%$ of esophagus intubations. Similarly, chest expansion was detected in 100\% of trachea intubations but also yielded false positive results in $90 \%$ of esophagus intubations. We found similar results, however Andersen and Hald ${ }^{[7]}$ did not evaluate observation of the passing of ETT through vocal cords. In our study, sensitivity of lung auscultation was 100\% when evaluated alone, however it yielded false positive results in $18 \%$ of esophagus intubations. When we evaluated stomach auscultation, its specificity was $100 \%$, but yielded false negative results in $10 \%$. When we evaluated lung and stomach auscultation together, sensitivity and specificity were found as $100 \%$. When we evaluated chest expansion and blurring of the tube, we found them to have high false positivity and low diagnostic value, similar to that study. ${ }^{[7]}$

In a study conducted with 345 cases, Grmec ${ }^{[8]}$ compared auscultation, capnometry, and capnography and also used direct observation of ETT location with laryngoscopy. He evaluated bilateral and equal sounds with lung auscultation, not hearing sound on stomach auscultation and 
chest wall movements together. Patients were divided into two groups as those who did and did not experience cardiac arrest. While sensitivity of auscultation was $100 \%$, specificity was $80 \%$ in patients who experienced cardiac arrest, sensitivity was found as $94 \%$ and specificity as $83 \%$ in patients who did not experience cardiac arrest. Sensitivity of capnometry was found lower than auscultation and capnography in patients who had cardiac arrest. Capnography had 100\% sensitivity and specificity in all conditions. We used capnography as the gold standard for confirming the ETT position in our study. Capnography was accepted as the gold standard method in 2010. However it was not considered the gold standard in 2002 when $\mathrm{Grmec}^{[8]}$ had conducted the study. We evaluated the parameters individually that had been evaluated together by Grmec; ${ }^{[8]}$ we evaluated lung and stomach auscultation together. We observed that hearing bilateral and equal lung sounds, and not hearing sounds on stomach auscultation were very valuable for confirming ETT position, and that bilateral and equal chest expansion was a method with low diagnostic value.

Brunel et al. ${ }^{[9]}$ compared physical examination findings and chest X-ray for confirmation of ETT position in their study conducted with 219 cases. Physical examination findings included hearing respiratory sounds from the fourth intercostal space at bilateral mid-axillar line, symmetrical chest wall movements, and assessment of whether ETT balloon was at suprasternal point. 97\% of the operators were seen to suggest that they correctly placed the ETT, ratio of detecting a wrong position was found as $14 \%$. While respiratory sounds were found to be equal in $60 \%$ of the patients, chest wall movements were detected to be equal and symmetrical in 70\% of the patients. That study had not evaluated stomach auscultation, the tube's passing through vocal cords, and blurring of the tube. The authors reported that physical examination findings were irrelevant and recommended chest X-ray after intubation for confirmation of the position of the ETT. However chest X-rays was also found to be impractical for this purpose since leads to delay in verifying the position of the tube and also exposure to unnecessary radiation. ${ }^{[10]}$ Although lung auscultation was detected to have a low diagnostic value in that study, we detected it to be a very valuable method in our study. We believe the low diagnostic value of lung auscultation found in Brunnel's ${ }^{[9]}$ study may be associated with the auscultation sites. We also found diagnostic value of chest movements to be low as in that study. ${ }^{[9]}$

Reliability of blurring of the ETT for confirming the ETT position was investigated in the animal study conducted by Kelly et al. ${ }^{[1]}$ Serial arterial blood gas measurement was used as the gold standard. Two groups were created, as trachea intubation and stomach intubation; each tube was ventilated for five times and evaluated according to the presence of blurring in the tube. While ratio of blurring was $100 \%$ in trachea intubation group, this was $83 \%$ in the esophagus intubation group. The authors concluded that blurring of the tube is an unreliable method. ${ }^{[1]}$ We also detected the diagnostic value of blurring of the tube to be low. While sensitivity of the method was 96\%, specificity was 50\%. We concluded that ETT position is incorrect in patients in whom blurring of the tube was not observed. Positivity of tube blurring is an impractical method for confirmation of ETT position and is a method with low clinical diagnostic value.

Due to their high diagnostic value, we believe that the tube's passing through the vocal cords, bilateral lung auscultation, and stomach auscultation could be used instead of capnography for confirmation of ETT position in EDs when capnography is unavailable.

\section{Limitations}

Our study had some limitations. The first was the low number of patients. Prospective studies conducted with larger number of patients are necessary to verify the results of our study. The second limitation was the single center design of the study, so our data may not unapplicable to the other centers.

\section{Conclusion}

We concluded that the tube's passing through vocal cords, hearing bilateral and equal sounds in lung auscultation, and not hearing sounds in stomach auscultation could be used clinically in confirming the ETT position when the gold standard method, capnography, is unavailable; however their combined use is more valuable. We believe that the use of conventional methods is still effective and reliable for confirmation of ETT position. 


\section{Declaration of conflicting interests}

The authors declared no conflicts of interest with respect to the authorship and/or publication of this article.

\section{Funding}

The authors received no financial support for the research and/or authorship of this article.

\section{REFERENCES}

1. Chou HC, Tseng WP, Wang $\mathrm{CH}$, Ma MH, Wang HP, Huang PC, et al. Tracheal rapid ultrasound exam (T.R.U.E.) for confirming endotracheal tube placement during emergency intubation. Resuscitation 2011;82:1279-84.

2. Guidelines 2000 for Cardiopulmonary Resuscitation and Emergency Cardiovascular Care. Part 6: advanced cardiovascular life support: section 1: Introduction to ACLS 2000: overview of recommended changes in ACLS from the guidelines 2000 conference. The American Heart Association in collaboration with the International Liaison Committee on Resuscitation. Circulation 2000;102(8 Suppl):I86-9.

3. Neumar RW, Otto CW, Link MS, Kronick SL, Shuster M, Callaway CW, et al. Part 8: adult advanced cardiovascular life support: 2010 American Heart Association Guidelines for Cardiopulmonary Resuscitation and Emergency Cardiovascular Care. Circulation 2010;122(18 Suppl 3):S729-67.

4. Deiorio NM. Continuous end-tidal carbon dioxide monitoring for confirmation of endotracheal tube placement is neither widely available nor consistently applied by emergency physicians. Emerg Med J 2005;22:490-3.

5. Carlson JN, Wang HE. Noninvasive airway management. In: Tintinalli JE, Stapczynski JS, Ma OJ, Yealy D, Meckler GD, Cline DM, , editors. Tintinalli's Emergency Medicine: A Comprehensive Study Guide. 8th ed. New York: McGraw-Hill; 2016. p. $178-83$.

6. Nagler J, Krauss B. Capnography: a valuable tool for airway management. Emerg Med Clin North Am 2008;26:881-97.

7. Andersen $\mathrm{KH}$, Hald $\mathrm{A}$. Assessing the position of the tracheal tube. The reliability of different methods. Anaesthesia 1989;44:984-5.

8. Grmec S. Comparison of three different methods to confirm tracheal tube placement in emergency intubation. Intensive Care Med 2002;28:701-4.

9. Brunel W, Coleman DL, Schwartz DE, Peper E, Cohen $\mathrm{NH}$. Assessment of routine chest roentgenograms and the physical examination to confirm endotracheal tube position. Chest 1989;96:1043-5.

10. American College of Emergency Physicians. Verification of endotracheal tube placement. Policy statement; 2001.

11. Kelly JJ, Eynon CA, Kaplan JL, de Garavilla L, Dalsey WC. Use of tube condensation as an indicator of endotracheal tube placement. Ann Emerg Med 1998;31:575-8. 